\title{
Coagulase gene polymorphism of Staphylococcus aureus isolated from clinical and sub-clinical bovine mastitis in Isfahan and Chaharmahal va Bakhtiari provinces of Iran
}

\author{
Hassan Momtaz • Elahe Tajbakhsh • Ebrahim Rahimi • \\ Manochehr Momeni
}

Received: 9 January 2010 / Accepted: 26 May 2010 /Published online: 16 June 2010

(C) The Author(s) 2010. This article is published with open access at Springerlink.com

\begin{abstract}
Mastitis is a common disease in dairy cattle and is an inflammatory response of the breast tissue to bacterial attack to this tissue. Mastitis causes considerable loss to the dairy industry, among the several bacterial pathogens that can cause mastitis; Staphylococcus aureus is probably the most lethal agent because it causes chronic and deep infection in the mammary glands that is extremely difficult to cure. Several virulence factors including coagulase gene are produced by $S$. aureus and may contribute to its pathogenicity. This study was conducted to investigate the coagulase gene polymorphism of $S$. aureus isolated from clinical and sub-clinical bovine mastitis milk samples in Isfahan and Chaharmahal va Bakhtiari provinces of Iran.
\end{abstract}

\footnotetext{
H. Momtaz $(\bowtie)$

Department of Microbiology, Faculty of Veterinary Medicine, Islamic Azad University,

P.O. Box166, Shahrekord Branch,

Shahrekord, Iran

e-mail: hamomtaz@iaushk.ac.ir

E. Tajbakhsh

Department of Microbiology, Faculty of Basic Sciences, Islamic Azad University,

Shahrekord Branch,

Shahrekord, Iran

E. Rahimi

Department of Food Hygienic, Faculty of Veterinary Medicine, Islamic Azad University,

Shahrekord Branch,

Shahrekord, Iran

\section{Momeni}

Research center of Biotechnology, Faculty of Veterinary

Medicine, Islamic Azad University,

Shahrekord Branch,

Shahrekord, Iran
}

Amplification of the coagulase gene from $86 \mathrm{~S}$. aureus strains isolates by specific primers showed 31 specimens contained $970 \mathrm{bp}$ fragment, and 11 strains contained $730 \mathrm{bp}$ fragment relevant to coa gene (coagulase) in PCR. After enzymatic digestion with $A l u \mathrm{I}, 31$ specimens contained three bands: 320, 490, and 160 bp (genotype I) and 11 specimens contained two bands: 490 and 240 bp (genotype VIII) in the RFLP.

Keywords Staphylococcus aureus · Bovine mastitis · PCR · Polymorphism · Coagulase gene $\cdot$ Iran

\section{Introduction}

Bovine mastitis is a major disease that affects the dairy industry, and Staphylococcus aureus is one of the most frequently isolated pathogens from both sub-clinical and chronic infections (Watts 1988). Currently used comprehensive mastitis control protocols have decreased the incidence, but $S$. aureus still remains one of the most significant organisms associated with clinical and subclinical bovine mastitis, not only in the USA but worldwide. A better understanding of the epidemiology of $S$. aureus is needed for the improvement of current mastitis control protocols. In the past decade, numerous molecular techniques have been developed and used for the identification and comparison of $S$. aureus isolates in epidemiological studies. Among these methods, coagulase gene typing has proven to be a simple and effective means to identify coagulase-positive $S$. aureus isolates from both human and animal sources (Aarestrup et al. 1995; Goh et al. 1992; Hookey et al. 1998; Kobayashi et al. 1995; Lawrence et al. 1996; Nada et al. 1996; Schwarzkopf and Karch 1994; Su et al. 1999; Tenover et al. 1994). 
In Iran, little information is available on the genetic diversity of $S$. aureus isolated from cows with clinical and sub-clinical bovine mastitis. In this study, coa gene polymorphism was used for typing and differentiation of $S$. aureus strains isolated from bovine mastitic milk samples from two different provinces in Iran.

\section{Materials and methods}

Bacterial isolates A total of $86 \mathrm{~S}$. aureus isolates from Chaharmahal va Bakhtiari $(n=30)$ and Isfahan $(n=56)$ were isolated from 360 clinical and sub-clinical bovine mastitic milk samples (140 samples from Chaharmahal va Bakhtiari and 220 samples from Isfahan). Milk samples were inoculated onto blood agar base (Merck) supplemented with 5\% defibrinated sheep blood. Isolates were identified by conventional methods, including Gram staining, colony morphology, hemolysis, tests for catalase, clumping factor, DNase, acetoin, and anaerobic fermentation of mannitol.

Extraction and purification of DNA Bacterial DNA extraction was carried out according to Rodrigues da Silva and da Silva (2005). Bacterial cell lysate was prepared from $0.5 \mathrm{ml}$ of overnight trypticase soy broth cultures. After centrifugation at $12,000 \times g$ for $10 \mathrm{~min}$, bacterial pellets were washed with $500 \mu$ of Tris-hydrochloride-ethylene diamine tetra acetic acid (TE) buffer (10 mM Tris- $\mathrm{HCl}, \mathrm{pH} 7.5$, and $1 \mathrm{mM}$ EDTA) and centrifuged again. The pellets were resuspended in $200 \mu \mathrm{l}$ of TE buffer ( $\mathrm{pH} 7.5)$ with $15 \mathrm{U}$ of lysostaphin (2 mg, Sigma) per milliliter and incubated at $37^{\circ} \mathrm{C}$ for $1 \mathrm{~h}$. Next, $15 \mu \mathrm{l}$ of proteinase $\mathrm{K}(20 \mathrm{mg} / \mathrm{ml}$; Fermentas) was added, and the suspension was incubated at $56^{\circ} \mathrm{C}$ for $1 \mathrm{~h}$. The suspension was then heated at $95^{\circ} \mathrm{C}$ for 15 min to inactivate the proteinase K. An equal volume of phenol-chloroform was added and the mixture centrifuged at $12,000 \times g$ for $10 \mathrm{~min}$. The upper phase was carefully transferred into another Eppendorf tube and mixed with two volumes of $95 \%$ ethanol and stored overnight at $-20^{\circ} \mathrm{C}$. The mixture was then centrifuged at $12,000 \times \mathrm{g}$ for $5 \mathrm{~min}$. The DNA pellet was washed with ice-cold $70 \%$ ethanol, recentrifuged, and dried by tube inversion. The DNA was suspended in $100 \mu$ of sterile TE, quantified in a spectrophotometer (at $260 \mathrm{~nm}$ ), and kept frozen at $-20^{\circ} \mathrm{C}$.

Polymerase chain reaction (PCR) amplification PCR was performed in a 50- $\mu$ l reaction mixture containing $2 \mu \mathrm{l}$ of template DNA (approximately $500 \mathrm{ng} / \mu \mathrm{l}$ ), $5 \mu \mathrm{l}$ of $10 \times \mathrm{PCR}$ buffer $\left(750 \mathrm{mM}\right.$ Tris- $\mathrm{HCl}(\mathrm{pH} 8.8), 200 \mathrm{mM}\left(\mathrm{NH}_{4}\right)_{2} \mathrm{SO}_{4}$, and $0.1 \%$ Tween 20), $200 \mu \mathrm{M}$ of each of the four deoxynucleotide triphosphates, $1 \mathrm{U}$ of Taq DNA polymerase (Roch Applied Science), and 50 pmol of each primer (COAG2: CGA GAC CAA GAT TCA ACA AG; COAG3-
AAA GAA AAC CAC TCA CAT CA). The PCR reaction was performed in a thermocycler (Eppendorf, Mastercycler ${ }^{\circledR}$ 5330, Eppendorf-Netheler-Hinz GmbH, Hamburg, Germany) using the following cyclic conditions: initial denaturation at $95^{\circ} \mathrm{C}$ for $2 \mathrm{~min}, 30$ cycles of $30 \mathrm{~s}$ each with denaturation at $95^{\circ} \mathrm{C}, 2 \mathrm{~min}$ annealing at $58^{\circ} \mathrm{C}, 4 \mathrm{~min}$ extension at $72^{\circ} \mathrm{C}$, and a final $7 \mathrm{~min}$ extension at $72^{\circ} \mathrm{C}$ (Goh et al. 1992).

Restriction enzyme digestion The PCR products were digested with AluI (Fermentas) for restriction analysis. For this aim, $12.5 \mu \mathrm{l}$ of PCR products was mixed with $10 \mathrm{U}$ of enzyme and $10 \times 1.5 \mu \mathrm{l}$ restriction buffer and then incubated at $37^{\circ} \mathrm{C}$ overnight (Aslantas et al. 2007).

Agarose gel electrophoresis The PCR products and the digested fragments were separated in $1 \%$ and $3 \%$ agarose gel (Fermentas), respectively, with $10 \mathrm{mg} / \mathrm{ml}$ aqueous solution of ethidium bromide (Fermentas) and then were photographed under ultraviolet illumination. The 100-bp marker (Fermentas) was used as a size standard for the calculation of the sizes of the coa and AluI-generated coa fragments.

\section{Results}

A total of 360 clinical and sub-clinical bovine mastitic milk samples from several major herds in the Chaharmahal va Bakhtiari and Isfahan provinces were used in this study. Eighty-six specimens $(23.88 \%)$ from these samples were identified as infected with $S$. aureus in microbiological studies.

The PCR assay was able to detect $S$. aureus DNA from 86 samples of milk by using primers mentioned in the Materials and methods above. Eighty-six specimens

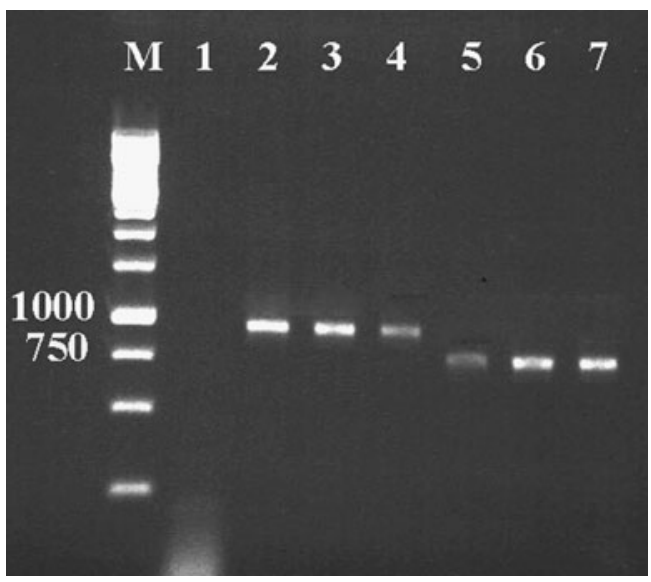

Fig. 1 Agarose gel electrophoresis of coa gene. Line $M 1 \mathrm{~kb}$ DNA ladder, line 1 negative control, lines 2-4 positive samples with 970-bp fragment; lines 5-7 positive samples with 730 -bp fragment 
Table 1 Relationship between severity of mastitis (from the viewpoint of CMT test) and presence of the coa gene in the Staphylococcus aureus strain isolated from the cases of bovine mastitis

\begin{tabular}{lrl}
\hline Specimens & coa & Degree of CMT \\
\hline 20 & 7 & CMT + \\
45 & 12 & CMT ++ \\
21 & 23 & CMT +++ \\
\hline
\end{tabular}

contained 1,250-bp DNA fragment of the 23srRNA for $S$. aureus.

From the total of 86 bacterial strains isolated in this study, 42 of them contained the coa gene. The results are shown in Fig. 1:

S. aureus strains isolated in this study are relevant to the clinical and sub-clinical mastitis which in the California mastitis test (CMT) test had shown positive reactions. From the total of 86 strains isolated in this study, 20 specimens were $1+$ mastitis (in CMT test); 45 specimens were 2+ mastitis, and 21 specimens were $3+$ mastitis. The number of coa gene of $S$. aureus are shown in Table 1.

Restriction fragment length polymorphism (RFLP) was used to determine the polymorphism of the coagulase gene from the 42 strains of $S$. aureus isolated in this study. Thirty-one strains contained $970 \mathrm{bp}$, and 11 strains contained 730-bp fragment relevant to coa gene in the PCR. After enzymatic digestion with AluI in the PCR,

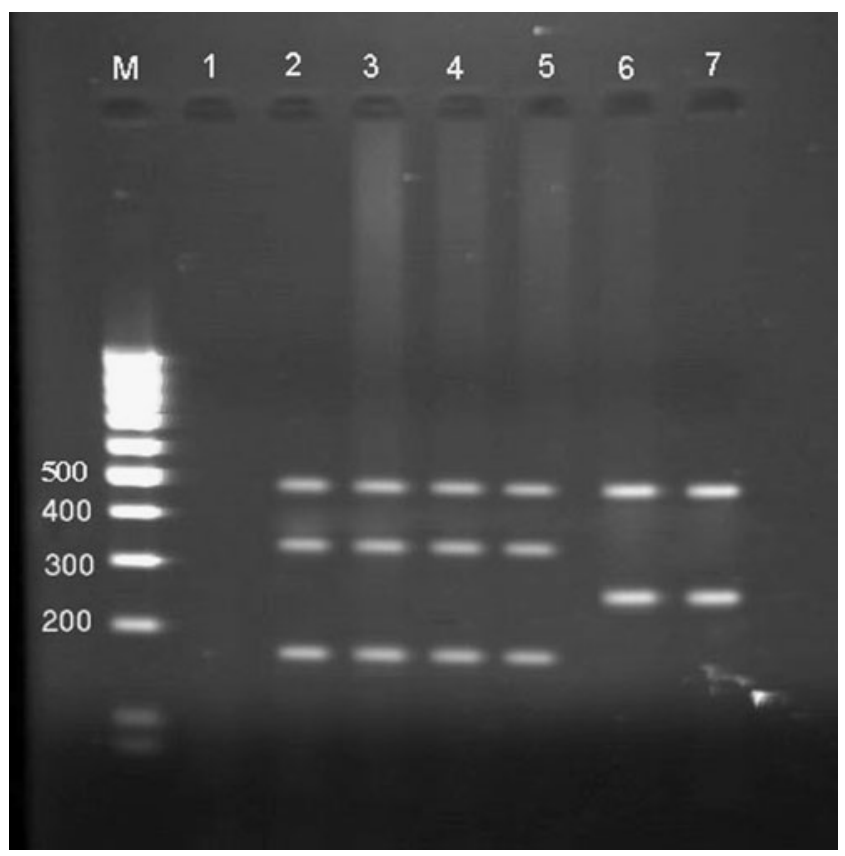

Fig. 2 Agarose gel electrophoresis, RFLP of the coa gene $S$. aureus strains isolated from bovine mastitis milk. Line M $100 \mathrm{bp}$ DNA ladder, line 1 negative control, lines 2-5 genotype I coa gene, lines 6-7 genotype VIII coa gene products indicated that 31 strains contained three bands of 490,320 , and $160 \mathrm{bp}$ and 11 strains contained two bands of 490 and 240 bp. The results are shown in Fig. 2.

\section{Discussion}

The production of coagulase is an important feature used worldwide for the identification of $S$. aureus. The $3^{\prime}$ end of the coa gene contains a series of 81-bp tandem repeats, which differ among $S$. aureus isolates, both in their number and in the location of AluI restriction sites (Goh et al. 1992). Classification based on the coa gene of $S$. aureus isolated has been considered a simple and accurate method for molecular typing (Goh et al. 1992; Rodrigues da Silva and da Silva 2005). Raimundo et al. (1999) reported that this technique could be used in epidemiological investigations of $S$. aureus isolates from bovine mastitis because of its high reproducibility and good discriminatory power, it is the easiest with which to analyze coa gene polymorphism among a large number of bacterial isolates, and it generates multiple distinct polymorphism patterns (Raimundo et al. 1999).

Among the 86 S. aureus strains, 31 strains contained $970 \mathrm{bp}$ fragment, and 11 strains contained $730 \mathrm{bp}$ fragments relevant to the coa gene. Following enzymatic digestion with the $A l u \mathrm{I}$, five different models were observed in the RFLP test such that 31 strains of genotype I contained three separate bands of 490, 320, and $160 \mathrm{bp}$, and 11 strains relevant to genotype VIII contained two bands of 490 and 240 bp (Fig. 2). These results indicate a considerable heterogeneity in the coa gene of the strains isolated in the Chaharmahal va Bakhtiari and Isfahan provinces, and as shown by $\mathrm{Su}$ et al. and Aarestrup et al., in each country, a special genotype is dominant (Aarestrup et al. 1995; Su et al. 2000).

Results of similar studies correspond with ours. In two studies performed by $\mathrm{Su}$ et al. (1999) and Aarestrup et al. (1995), 83.3\% of the isolated strains in the Hatay region were relevant to type I, and $65.4 \%$ were relevant to type VIII of coagulase.

A study by Aslantas et al. (2007) from Turkey indicated greater variability of RFLP models of coa gene of the $S$. aureus strains isolated from bovine mastitis cases.

This variation is relevant to the bacterial pool, hard management, and environmental conditions in each geographical region. In this study, polymorphism model of the coa gene, as individual bands measuring 730 to $970 \mathrm{bp}$, was observed (Aslantas et al. 2007; Goh et al. 1992; Rodrigues da Silva and da Silva 2005). In samples from Brazil, a double bond from the reproduced products of coa gene in the strains isolated from the bovine mastitis cases has been reported (Rodrigues da Silva and da Silva 2005). 
In the study performed by Karahan and Cetinkaya (2007) in Turkey, of the 200 strains of $S$. aureus isolated from 700 milk samples of cows bovine mastitis milk samples, 16 samples contained coa gene, which were positive following RFLP with the AluI and HinGI enzymes; 23 and 22 bands were observed in the electrophoresis model, respectively.

Saei et al. (2009) in 58 S. aureus strains isolated from 370 bovine mastitis milk samples reported 490 to $850 \mathrm{bp}$ fragment from PCR product after digestion with HaeIII enzyme, $39.66 \%$ of the strains were relevant to genotype I, and $24.14 \%$ of strains were relevant to genotype VIII coagulase.

As a whole, results obtained from this study indicate that cases of mastitis in cattle husbandries in the Chaharmahal va Bakhtiari and Isfahan provinces in Iran are caused by certain strains of $S$. aureus mostly carrying a coagulase genotype and/or 1 or 2 genotypes of the coa gene is predominant in them. This information might help better control and managing of cases of mastitis caused by $S$. aureus.

Acknowledgements We thank Dr. A. Sharifzadeh, Dr. M. Moradi, Dr. S. Seidali, and Dr. O. Ghorbani for their cooperation. This work was supported by the Islamic Azad University, Shahr-e-kord Branch in Iran.

Open Access This article is distributed under the terms of the Creative Commons Attribution Noncommercial License which permits any noncommercial use, distribution, and reproduction in any medium, provided the original author(s) and source are credited.

\section{References}

Aarestrup FM, Dangler CA, Sordillo LM (1995) Prevalence of coagulase gene polymorphism in Staphylococcus aureus isolates causing bovine mastitis. Can J Vet Res 59:124-128, PMID: 7648524

Aslantas O, Demir C, Turutoglu H, Cantekin Z, Ergun Y, Dogruer G (2007) Cagulase gene polymorphism of Staphylococcus aureus isolated form subclinical mastitis. Turk J Vet Anim Sci 31:253257, http://journals.tubitak.gov.tr/veterinary/issues/vet-07-31-4/ vet-31-4-7-0609-8.pdf

Goh S, Byrne SK, Zhang JL, Chow AW (1992) Molecular typing of Staphylococcus aureus on the basis of coagulase gene polymorphisms. J Clin Microbiol 30:1642-1645, PMID: 1352784
Hookey JV, Richardson JF, Cookson BD (1998) Molecular typing of Staphylococcus aureus based on PCR restriction fragment length polymorphism and DNA sequence analysis of the coagulase gene. J Clin Microbiol 36:1083-1089, PMID: 9542942

Karahan M, Cetinkaya B (2007) Coagulase gen polymorphism detected by PCR in Staphylococcus aureus isolated form subclinical bovine mastitis in Turkey. Vet $\mathrm{J}$ 174:428-431. doi:10.1016/j.tvj1.2006.05.016

Kobayashi N, Taniguchi K, Kojima K, Urasawa S, Uehara N, Omizu Y, Kishi Y, Yagihashi A, Kurokawa I (1995) Analysis of methicillin-resistant and methicillin-susceptible Staphylococcus aureus by a molecular typing method based on coagulase gene polymorphism. Epidemiol Infect 115:419-426, PMID: 8557073

Lawrence C, Cosseron M, Mimoz O, Brun-Buisson C, Costa Y, Sammii K, Duval J, Leclercq R (1996) Use of the coagulase gene typing method for the detection of carriers of methicillin-resistant Staphylococcus aureus. J Antimicrob Chemother 37:687-696, PMID: 8722534

Nada T, Ichiyama S, Osada Y, Ohta M, Shimokata K, Kato N, Nakashima N (1996) Comparison of DNA fingerprinting by PFGE and PCR-RFLP of the coagulase gene to distinguish MRSA isolates. J Hosp Infect 32:305-317, PMID: 8744515

Raimundo O, Deighton M, Capstick J, Gerraty N (1999) Molecular typing of Staphylococcus aureus of bovine origin by polymorphisms of the coagulase gene. Vet Microbiol 66:275-284. doi:10.1016/S0378-1135(99)00020-6

Rodrigues da Silva E, da Silva N (2005) Coagulase gene typing of Staphylococcus aureus isolated from cows with mastitis in southern Brazil. Can J Vet Res 69:260-264, PMID: 16479723

Saei HD, Ahmadi M, Mardani K, Batavani RA (2009) Molecular typing of Staphylococcus aureus isolated from bovine mastitis based on polymorphism of the coagulase gene in the north west of Iran. Vet Microbiol 137:202-206, PMID: 19195799

Schwarzkopf A, Karch H (1994) Genetic variation in Staphylococcus aureus coagulase: potential and limits for use as epidemiological marker. J Clin Microbiol 32:2407-2412, PMID: 7814475

Su C, Herbelin C, Frieze N, Skardova O, Sordillo LM (1999) Coagulase gene polymorphism of Staphylococcus aureus isolates from dairy cattle in different geographical areas. Epidemiol Infect 122:329-336, PMID: 10355800

Su C, Kanevsky I, Jayarao BM, Sordillo LM (2000) Phylogenetic relationships of Staphylococcus aureus from bovine mastitis based on coagulase gene polymorphism. Vet Microbiol 71:5358, PMID: 10665533

Tenover FC, Arbeit R, Archer G, Biddle J, Byrne S, Goering R, Hancock G, Hebert GA, Hill B, Hollis R, Jarvis WR, Kreiswirth B, Eisner W, Maslow J, McDougal LK, Miller JM, Mulligan M, Pfaller MA (1994) Comparison of traditional and molecular methods of typing isolates of Staphylococcus aureus. J Clin Microbiol 32:407-415, PMID: 7908673

Watts JL (1988) Etiological agents of bovine mastitis. Vet Microbiol 16:41-66, PMID: 3354192 